\title{
Development of New High-Strength Carbide-Free Bainitic Steels
}

\author{
S. SHARMA, S. SANGAL, and K. MONDAL
}

An attempt was made to optimize the mechanical properties by tailoring the process parameters for two newly developed high-strength carbide-free bainitic steels with the nominal compositions of 0.47 pct $\mathrm{C}, 1.22$ pet $\mathrm{Si}, 1.07$ pct $\mathrm{Mn}, 0.7$ pet $\mathrm{Cr}(\mathrm{S} 1)$, and 0.30 pct $\mathrm{C}, 1.76$ pet $\mathrm{Si}$, $1.57 \mathrm{pct} \mathrm{Mn}$, and $0.144 \mathrm{pct} \mathrm{Cr}$ (S2) (wt pct), respectively. Heat treatment was carried out via two different routes: (1) isothermal transformation and (2) quenching followed by isothermal tempering. The results for the two different processes were compared. The bainitic steels developed by isothermal heat treatment were found to show better mechanical properties than those of the quenched and subsequently tempered ones. The effect of the fraction of the phases, influence of the transformation temperatures, the holding time, and the stability of retained austenite on the mechanical properties of these two steels was critically analyzed with the help of X-ray diffraction, optical metallography, scanning electron microscopy, and atomic force microscopy. Finally, a remarkable combination of yield strength of the level of $1557 \mathrm{MPa}$ with a total elongation of 15.5 pct was obtained.

DOI: $10.1007 / \mathrm{s} 11661-011-0797-6$

(C) The Minerals, Metals \& Materials Society and ASM International 2011

\section{INTRODUCTION}

CARBIDE-FREE bainitic steels are emerging as a very promising class of steels, because they exhibit a remarkable combination of high strength with good ductility and can be produced at low costs. ${ }^{[1]}$ The mechanical properties of carbide-free bainitic steels were found to supersede those of quenched and tempered alloys of the same hardness because of their interesting microstructure consisting of thin plates of bainite in a matrix of retained austenite. This microstructure can be generated by quenching to a certain temperature followed by a simple isothermal holding treatment route. The strength of these steels is due to the small length scale of the microstructure (relative fineness of bainite lathes) and high dislocation densities, whereas ductility was attributed to the film of retained austenite present in between the bainitic lathes. ${ }^{[2-4]}$ The detrimental effect of carbides is overcome by suppressing their precipitation with the addition of a sufficient amount of silicon, ${ }^{[5,6]}$ and the thin film of austenite acts as a cushion for any crack propagation. ${ }^{[7,8]}$ A carbon-enriched austenite results in increased stability and thereby helps in minimizing the fraction of retained austenite transforming to martensite. ${ }^{[9]} \mathrm{A}$ series of bainitic steels with strengths more than $1200 \mathrm{MPa}$ along with an elongation of 13 pct can be used as high performance alloys possessing good toughness and tribological properties. $^{[10]}$ The design criterion for the development of very

S. SHARMA, Research Scholar, S. SANGAL, Professor, and K. MONDAL, Assistant Professor, are with the Department of Materials Science and Engineering, Indian Institute of Technology, Kanpur 208016, India. Contact e-mail: kallol@iitk.ac.in

Manuscript submitted December 13, 2010.

Article published online August 9, 2011 strong bainitic steels lies in the engineering of metastable temperature $\left(T_{o}\right)$ where the free energies of austenite and ferrite are the same. Coarse blocks of retained austenite can be avoided by shifting the $T_{0}$ curve to higher carbon concentrations in austenite. ${ }^{[10-12]}$ One of the best combinations of strength and toughness was achieved in a bainitic steel exhibiting $1600 \mathrm{MPa}$ and $130 \mathrm{MPa} \sqrt{\mathrm{m}}$, respectively, by meeting this criterion. ${ }^{[7,8]}$ Chakraborty et al. ${ }^{[13]}$ recently showed improved mechanical properties of 52100 steel $(1.1 \mathrm{C}, 1.46 \mathrm{Cr}, 0.27 \mathrm{Si}, 0.33 \mathrm{Mn}, 0.14 \mathrm{~V}$, $0.04 \mathrm{Ni}, 0.02 \mathrm{P}$, balance $\mathrm{Fe}$, all in wt pct) with a dualphase structure made of bainite and martensite over quenched and tempered structure by adopting the austempering route. Some prior cold deformation was given to refine the thickness and size of the bainitic sheaves. A maximum strength of $2250 \mathrm{MPa}$ with an impact strength of $72 \mathrm{~J}$ was achieved. Brown and Baxter ${ }^{[14]}$ found the isothermal transformation characteristics of a high carbon and high silicon steel, which exhibited a tensile yield stress of $1673 \mathrm{MPa}$ with an elongation of 8 pct. They designated them as super bainitic steels, which are virtually free of any carbides, and the sheaf thickness is very fine due to the low transformation temperatures of $473 \mathrm{~K}$ to $523 \mathrm{~K}\left(200{ }^{\circ} \mathrm{C}\right.$ to $250{ }^{\circ} \mathrm{C}$ ).

A recent trend in the field of bainitic steels is to develop carbide-free novel bainitic structures. ${ }^{[15,16]}$ The cementite particles in bainitic steels are detrimental to the properties as they are the source of crack and void nucleation. ${ }^{[10]}$ In the novel bainitic structures, these cementite precipitates are avoided by adding inhibitors such as Si and Al. It was shown ${ }^{[17]}$ that an addition of more than 1.5 wt pct Si results in carbide-free bainitic steels. Caballero and Bhadeshia ${ }^{[5]}$ have worked on designing novel high-strength steels and have successfully produced a mixed microstructure consisting of fine 
plates of upper bainitic ferrite separated by a thin film of retained austenite. They were able to achieve strength of $2500 \mathrm{MPa}$ and a toughness of 30 to $40 \mathrm{MPa} \sqrt{\mathrm{m}}$ at a transformation temperature of $398 \mathrm{~K}\left(125^{\circ} \mathrm{C}\right)$. With careful design, Caballero et al. ${ }^{[16]}$ were able to achieve an impressive combination of a toughness of $130 \mathrm{MPa} \sqrt{\mathrm{m}}$ with a strength of 1600 to $1700 \mathrm{MPa}$. However, the full benefit of carbide-free bainitic steels is yet to be realized. The alloy design and its incomplete reaction phenomena can further be explored to obtain more impressive properties. Present work investigates two steels with different compositions. They were treated isothermally at different temperatures as a function of time to form bainitic microstructure with different morphologies. The steels were also quenched to obtain martensite and subsequently tempered to obtain hardnesses similar to those of bainitic steels formed by isothermal treatment, and their mechanical properties were compared. The objective of the present work is to develop a structure-property correlation of carbide-free bainitic steels. It is shown that high strength in combination with high ductility can be obtained by suitable heat treatments.

\section{EXPERIMENTAL PROCEDURE}

Two medium carbon steels of different compositions were chosen. They are identified as S1 and S2. S1 is an EN45 grade material while $\mathrm{S} 2$ is a high silicon high manganese steel. Their chemical compositions are shown in Table I. The basic philosophy for choosing these alloy compositions (with high silicon and low carbon) is to obtain carbide-free bainitic morphology to achieve sufficient strength. Sufficient Mn is added so that some fraction of austenite is retained after transformation to give adequate ductility. The as-processed steels have a ferrite pearlite microstructure. To obtain a bainitic microstructure, the steels were austenitized at $1173 \mathrm{~K}\left(900{ }^{\circ} \mathrm{C}\right)$ for 20 minutes and then quenched in a salt bath kept at a desired isothermal transformation temperature within the bainitic start $\left(B_{s}\right)$ and the martensite start $\left(M_{s}\right)$ temperatures. The salt mixture used here consists of 80 pct $\mathrm{KNO}_{3}$ and 20 pct $\mathrm{NaNO}_{3}$. For both steels, the isothermal transformation temperatures were selected over a range between $B_{s}$ and $M_{s}$ temperatures. The bainitic and martensitic transformation temperatures were calculated by the following equations: ${ }^{[18,19]}$

$$
\begin{aligned}
M_{S}\left({ }^{\circ} \mathrm{C}\right)= & 539-423(\operatorname{pct} \mathrm{C})-30.4(\operatorname{pctMn}) \\
& -17.7(\operatorname{pctNi})-12.1(\operatorname{pct} \mathrm{Cr})-7.5(\mathrm{Mo}, \mathrm{W}, \mathrm{Si})
\end{aligned}
$$

$$
\begin{aligned}
B_{s}\left({ }^{\circ} \mathrm{C}\right)= & 630-45(\text { pct Mn })-40(\text { pct V })-35(\text { pct Si }) \\
& -30(\text { pct Cr })-25(\text { pct Mo })-20(\text { pct Ni }) \\
& -5(\text { pct })
\end{aligned}
$$

The calculated $B_{s}$ and $M_{s}$ temperatures for steels S1 and $\mathrm{S} 2$ are shown in Table I. Based on the preceding calculations, the isothermal transformation temperatures were kept at $573 \mathrm{~K}$ and $623 \mathrm{~K}\left(300{ }^{\circ} \mathrm{C}\right.$ and $\left.350{ }^{\circ} \mathrm{C}\right)$ for steel S1. In the case of steel S2, the transformation temperatures were chosen to be $598 \mathrm{~K}, 623 \mathrm{~K}, 648 \mathrm{~K}$, and $673 \mathrm{~K}\left(325{ }^{\circ} \mathrm{C}, 350{ }^{\circ} \mathrm{C}, 375{ }^{\circ} \mathrm{C}\right.$, and $\left.400{ }^{\circ} \mathrm{C}\right)$. The time duration for the transformation was varied from 10 to 120 minutes. The samples were also subjected to water quenching and tempering to achieve high hardness and strength levels. Samples were austenitized at $1173 \mathrm{~K}$ $\left(900{ }^{\circ} \mathrm{C}\right)$ for 20 minutes and water quenched. Tempering was done at $673 \mathrm{~K}\left(400{ }^{\circ} \mathrm{C}\right)$ for 60 minutes for steel S1 and at a temperature of $623 \mathrm{~K}\left(350^{\circ} \mathrm{C}\right)$ for 90 minutes for steel S2 in order to reduce the brittle behavior, and at the same time, the hardness of the quenched and subsequently tempered steel becomes nearly equal to that of the isothermally treated samples. The treatment routes and parameters followed in the case of both the transformation routes are shown in tabular form in Table II.

The amount of retained austenite in the heat-treated samples was determined by X-ray diffraction using $\mathrm{Cr}$ $K_{\alpha}$ radiation (wavelength $=2.2909 \AA$ ) in a Siefert ISODEBYEFLEX 1001 diffractometer (RICH SEIFERT \& Co. GmbH \& Co. KG, Ahrensburg, Germany) operated at $40 \mathrm{KV}$ and $30 \mathrm{~mA}$ fitted with a graphite monochro-

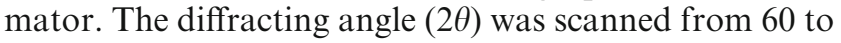
130 to include the strongest reflection from ferrite. The scan rate was 3 deg per minute with a step size of 0.05 . The optical metallography of the steel samples was carried out in a Zeiss optical microscope. Scanning electron microscopy (SEM) was carried out using an FEI Quanta scanning electron microscope (FEI Co., Hillsboro, OR) operated at $20 \mathrm{kV}$ using the secondary electron mode. In the case where martensite co-existed with bainite, quantitative analysis was done using image analyzer software. Atomic force microscopy (AFM) was also carried out to clearly reveal the ultrafine morphology of the heat-treated samples. There was also a need to see any other phases or carbides present in the microstructure. The AFM was done in the contact mode with a Solver Pro NT-MDT atomic force microscope (NT-MDT Co., Moscow, Russia) at a frequency of $1 \mathrm{KHz}$. The samples for metallography as well for AFM analysis were mechanically ground using emery paper down to mesh number 800 , followed by cloth polishing with $5-\mu \mathrm{m}$ and then $1-\mu \mathrm{m}$ alumina paste. They were etched with 2 pct nital to reveal the microstructure in optical microscopy and SEM. For AFM, these samples

Table I. Chemical Composition of the Investigated Steels S1 and S2

\begin{tabular}{lcccccccccccc}
\hline Element (Wt Pct) & $\mathrm{C}$ & $\mathrm{Si}$ & $\mathrm{Mn}$ & $\mathrm{Ni}$ & $\mathrm{Mo}$ & $\mathrm{Cr}$ & $\mathrm{S}$ & $\mathrm{Al}$ & $\mathrm{P}$ & $\mathrm{Fe}$ & $\mathrm{Bs}\left[\mathrm{K}\left({ }^{\circ} \mathrm{C}\right)\right]$ & $\mathrm{Ms}\left[\mathrm{K}\left({ }^{\circ} \mathrm{C}\right)\right]$ \\
\hline S1 & 0.47 & 1.22 & 1.07 & 0.04 & 0.01 & 0.7 & 0.01 & 0.01 & 0.01 & balance & $833(560)$ & $563(290)$ \\
S2 & 0.30 & 1.76 & 1.57 & 0.045 & 0.025 & 0.144 & 0.016 & 0.04 & 0.022 & balance & $765(492)$ & $579(306)$ \\
\hline
\end{tabular}


Table II. Different Heat Treatment Cycle Followed for Both the Steels S1 and S2

\begin{tabular}{|c|c|c|c|c|c|c|c|}
\hline \multicolumn{8}{|c|}{ Isothermal Transformation in Salt Bath } \\
\hline \multirow[b]{2}{*}{ Steel } & \multirow{2}{*}{$\begin{array}{c}\text { Soaking } \\
\text { Temperature } \\
\text { and Time }\end{array}$} & \multirow{2}{*}{$\begin{array}{c}\text { Salt Bath } \\
\text { Temperature } \\
{\left[\mathrm{K}\left({ }^{\circ} \mathrm{C}\right)\right]}\end{array}$} & \multicolumn{5}{|c|}{ Holding Time (Min) } \\
\hline & & & 10 & 30 & 60 & 90 & 120 \\
\hline \multirow[t]{2}{*}{$\mathrm{S} 1$} & $1173 \mathrm{~K}\left(900^{\circ} \mathrm{C}\right)$ for $20 \mathrm{~min}$ & $573(300)$ & $\mathrm{X}$ & $\sqrt{ }$ & $\sqrt{ }$ & $\sqrt{ }$ & $\mathrm{X}$ \\
\hline & & $623(350)$ & $\sqrt{ }$ & $\sqrt{ }$ & $\sqrt{ }$ & $\sqrt{ }$ & $\sqrt{ }$ \\
\hline \multirow[t]{4}{*}{ S2 } & $1173 \mathrm{~K}\left(900^{\circ} \mathrm{C}\right)$ for $20 \mathrm{~min}$ & $598(325)$ & $\sqrt{ }$ & $\sqrt{ }$ & $\sqrt{ }$ & $\sqrt{ }$ & $\sqrt{ }$ \\
\hline & & $623(350)$ & $\sqrt{ }$ & $\sqrt{ }$ & $\sqrt{ }$ & $\sqrt{ }$ & $\sqrt{ }$ \\
\hline & & $648(375)$ & $\sqrt{ }$ & $\sqrt{ }$ & $\sqrt{ }$ & $\sqrt{ }$ & $\sqrt{ }$ \\
\hline & & $673(400)$ & $\sqrt{ }$ & $\sqrt{ }$ & $\sqrt{ }$ & $\sqrt{ }$ & $\sqrt{ }$ \\
\hline \multicolumn{8}{|c|}{ Water quenching followed by isothermal tempering } \\
\hline Steel & Soaking Temperature and $\mathrm{T}$ & \multicolumn{6}{|c|}{ Tempering Temperature and Time } \\
\hline S1 & $1173 \mathrm{~K}\left(900^{\circ} \mathrm{C}\right)$ for $20 \mathrm{~min}$ & \multicolumn{6}{|c|}{$673 \mathrm{~K}\left(400^{\circ} \mathrm{C}\right)$ for $60 \mathrm{~min}$} \\
\hline S2 & $1173 \mathrm{~K}\left(900^{\circ} \mathrm{C}\right)$ for $20 \mathrm{~min}$ & \multicolumn{6}{|c|}{$623 \mathrm{~K}\left(350^{\circ} \mathrm{C}\right)$ for $90 \mathrm{~min}$} \\
\hline
\end{tabular}

Note: $\sqrt{ }$ - done, and $\mathrm{X}$ - not done.

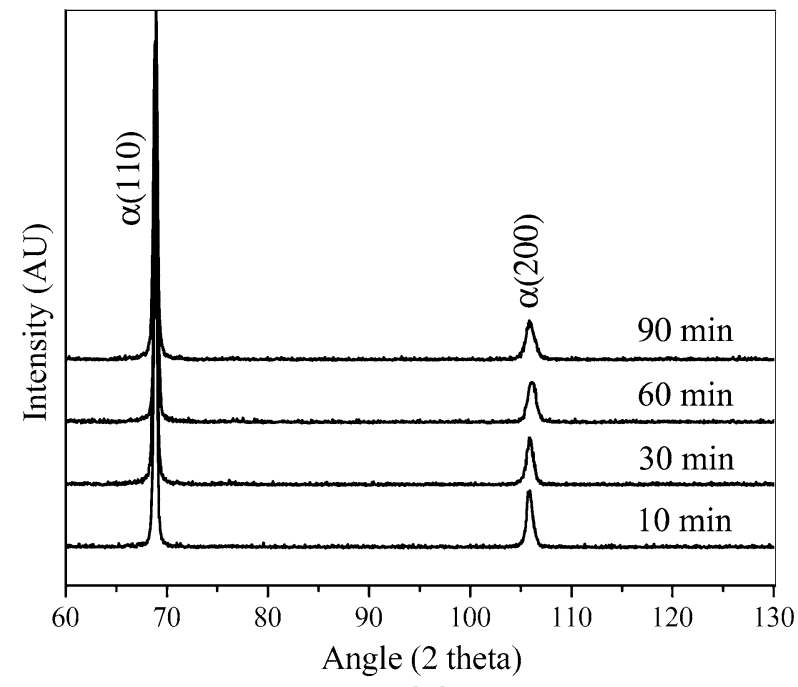

(a)

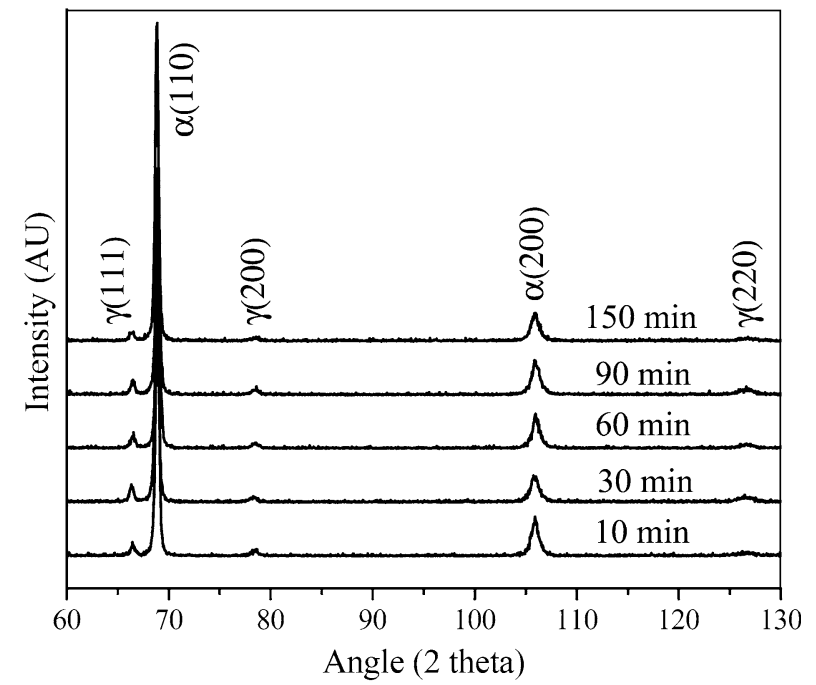

(b)

Fig. 1-X-ray diffraction patterns of $(a)$ steel $\mathrm{S} 1$ and $(b)$ steel S2, treated at $623 \mathrm{~K}\left(350{ }^{\circ} \mathrm{C}\right)$ for different isothermal holding durations.

were further polished with $0.1-\mu \mathrm{m}$ diamond paste and etched with 2 pct nital. Hardness measurements were done in a Rockwell hardness tester in $\mathrm{C}$ scale using $150 \mathrm{~kg}$ load and a Brale indenter (Wilson, American Chain \& Cable Co., New York). Tensile tests on the steel samples were carried out in a LR $10 \mathrm{~K}$ Lloyds Tensile Testing Machine (Lloyd Instrument Ltd., West Sussex, UK). The crosshead speed was kept at $0.2 \mathrm{~mm} / \mathrm{min}$ to maintain a strain rate of $2.66 \times 10^{-4} \mathrm{~s}^{1}$. The samples were made according to the ASTM E8M standards for subsize round specimen.

\section{RESULTS AND DISCUSSION}

Figures 1(a) and (b) show the XRD patterns of steels $\mathrm{S} 1$ and $\mathrm{S} 2$ at $623 \mathrm{~K}\left(350{ }^{\circ} \mathrm{C}\right)$ for different durations, respectively. The XRD patterns were indexed and a predominantly ferritic microstructure was observed. The presence of martensite is not reflected in the XRD patterns as peak splitting is not observed. This suggests that any martensite formed on water quenching after the isothermal transformation might be of low tetragonality and approximately of the same lattice parameter as that of ferrite. However, martensite was observed during metallographic analysis. The diffraction patterns of steel $\mathrm{S} 2$ in Figure 1(b) indicate the presence of ferrite and retained austenite. The XRD patterns did not show any carbide peaks. This suggests that the carbide precipitation was suppressed due to the presence of silicon, to the extent that the amount of carbide is below 1 pct (the threshold limit for its detection by XRD). The diffraction patterns of steel S2 in Figure 1(b) show the presence of retained austenite, which is completely absent in the XRD patterns for steel S1 in Figure 1(a). This indicates that in the steel $\mathrm{S} 1$ almost all the retained austenite transformed to martensite on water quenching from the salt bath. To complete the understanding of microstructural evolution, metallographic examinations of these steel samples were made, as discussed subsequently. 
Figures 2(a) through (d) show the optical micrographs of steel S1 heat treated at $623 \mathrm{~K}\left(350{ }^{\circ} \mathrm{C}\right)$ for $10,30,60$, and 90 minutes, respectively. Major fraction of the microstructures is bainite with some amount of martensite at all the holding durations. Figures 3(a) and (b) show the optical micrographs of $\mathrm{S} 1$ heat treated at isothermal transformation temperatures of $573 \mathrm{~K}$ and $623 \mathrm{~K}\left(300{ }^{\circ} \mathrm{C}\right.$ and $\left.350{ }^{\circ} \mathrm{C}\right)$ for a holding duration of 30 minutes, respectively. It was observed that at lower transformation temperature, the microstructure is more refined and the fraction of martensite is more than that at higher temperatures (Figures 3(a) and (b)). This can be attributed to the fact that at higher transformation temperatures, the rate of transformation is faster and the fraction of retained austenite available for the formation of martensite is less. Figures 4(a) and (b) show the SEM micrographs of steel S1 isothermally treated at $573 \mathrm{~K}$ and $623 \mathrm{~K}\left(300{ }^{\circ} \mathrm{C}\right.$ and $\left.350{ }^{\circ} \mathrm{C}\right)$ for 30 minutes. They show mainly a bainitic microstructure with some amount of martensite. The sheaflike structure is bainite and the less resolved regions are martensite, leading to an easy distinction between martensite and bainite.

Figures 5(a) through (d) show the optical micrographs of the steel S2 heat treated at isothermal transformation temperatures of $598 \mathrm{~K}, 623 \mathrm{~K}, 648 \mathrm{~K}$, and $673 \mathrm{~K}\left(325^{\circ} \mathrm{C}, 350{ }^{\circ} \mathrm{C}, 375^{\circ} \mathrm{C}\right.$, and $\left.400{ }^{\circ} \mathrm{C}\right)$ for 30 minutes, respectively. They clearly reveal a bainitic microstructure with retained austenite present as a film form. The difference in the size of the bainitic sheaves can also be observed. With the increase in temperature, there is a gradual increase in the thickness of the sheaves, as observed in Figures 5(a) through (d). It was also observed that the fraction of retained austenite decreases with the increase in holding temperature because of the faster kinetics for austenite to bainite transformation. It is found that at $598 \mathrm{~K}\left(325^{\circ} \mathrm{C}\right)$, some amount of martensite formed, while at higher transformation temperatures, the amount of martensite is almost negligible. Figures 6(a) through (d) show the SEM micrographs of the steel $\mathrm{S} 2$ treated at $598 \mathrm{~K}$, $623 \mathrm{~K}, 648 \mathrm{~K}$, and $673 \mathrm{~K}\left(325^{\circ} \mathrm{C}, 350{ }^{\circ} \mathrm{C}, 375^{\circ} \mathrm{C}\right.$, and $400{ }^{\circ} \mathrm{C}$ ) for 30 minutes, respectively. The retained austenite appears as smooth and featureless regions in these scanning electron micrographs. ${ }^{[1]}$ With the increase in isothermal holding temperature to $623 \mathrm{~K}\left(350{ }^{\circ} \mathrm{C}\right)$ (Figures 6(a) and (b)), there is a decrease in the fraction of retained austenite. However, the amount of retained austenite has further increased in the sample heat
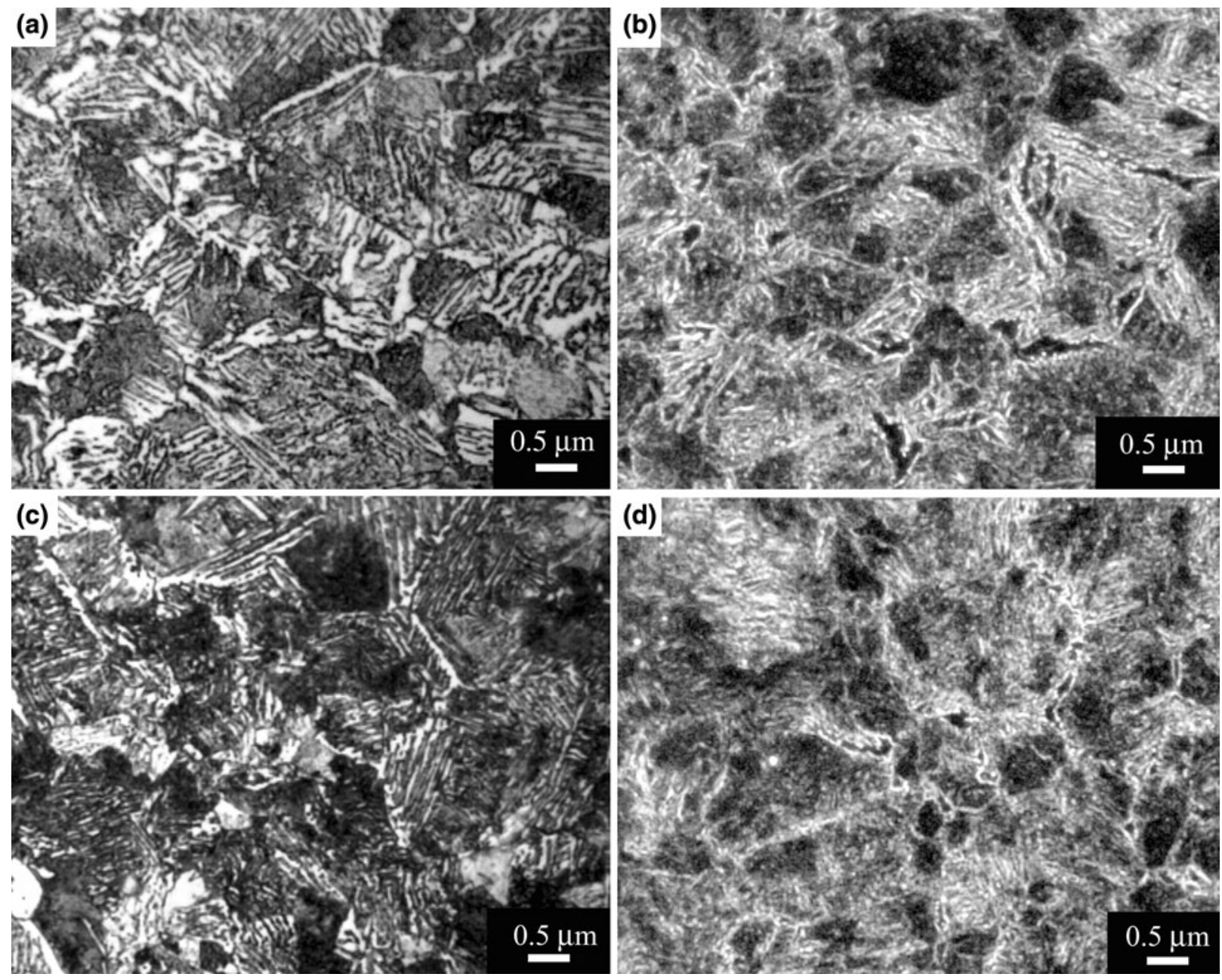

Fig. 2-Optical micrographs of steel S1 isothermally treated at $623 \mathrm{~K}\left(350{ }^{\circ} \mathrm{C}\right)$ for holding durations of $(a) 10 \mathrm{~min},($ b) $30 \mathrm{~min},(c) 60 \mathrm{~min}$, and (d) 90 min. 

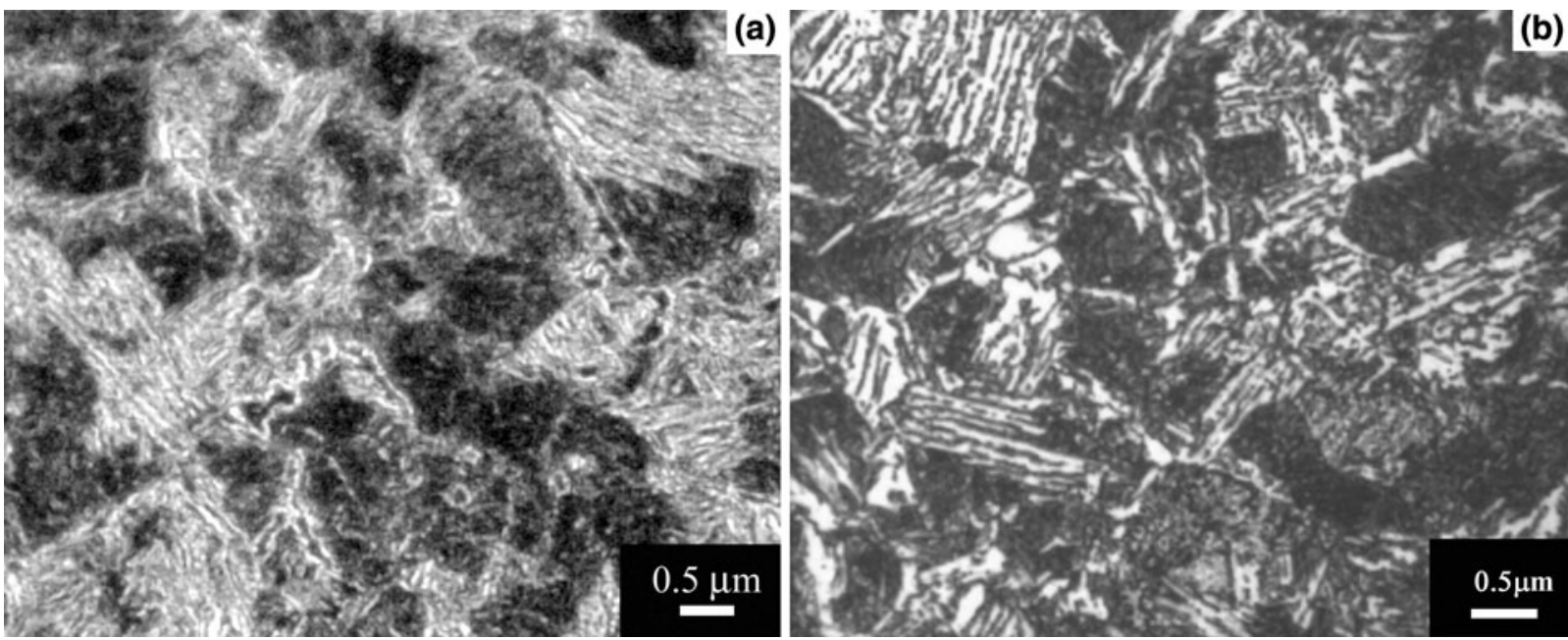

Fig. 3-Optical micrographs of steel S1 treated for a holding duration of 30 min for isothermal transformation temperatures of $(a) 573 \mathrm{~K}$ $\left(300{ }^{\circ} \mathrm{C}\right)$ and $(b) 623 \mathrm{~K}\left(350{ }^{\circ} \mathrm{C}\right)$.
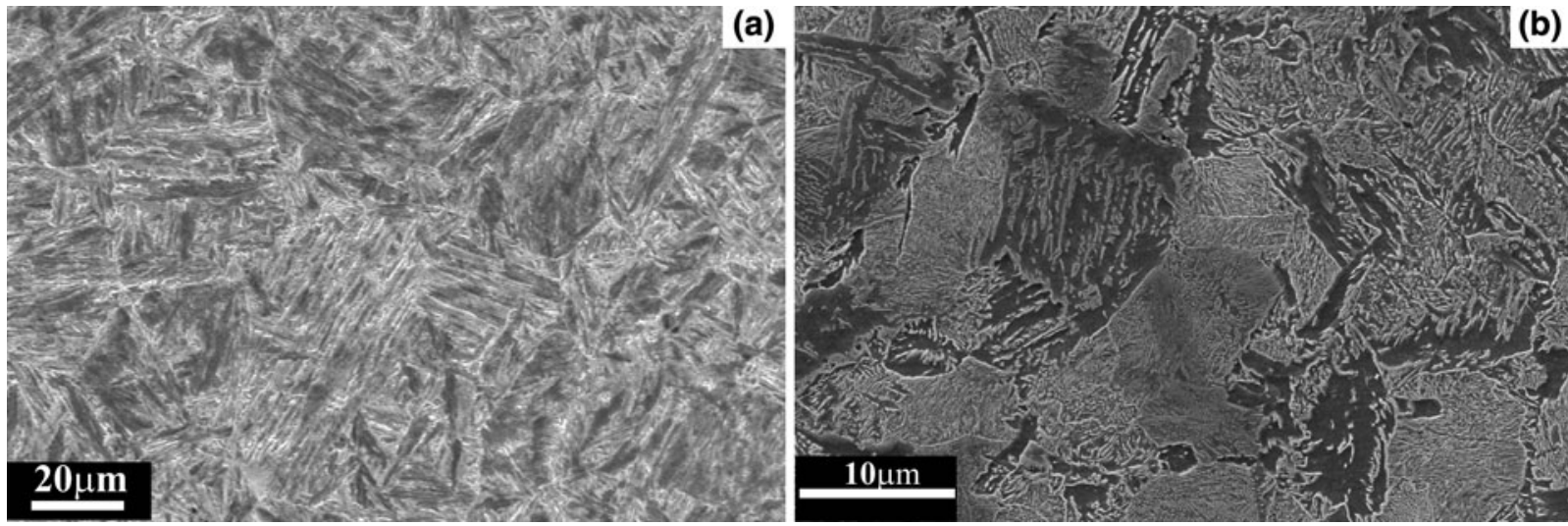

Fig. 4-SEM micrographs of steel S1 treated for a holding duration of $30 \mathrm{~min}$ at isothermal transformation temperatures of $(a) 573 \mathrm{~K}\left(300{ }^{\circ} \mathrm{C}\right)$ and $(b) 623 \mathrm{~K}\left(350^{\circ} \mathrm{C}\right)$.

treated at $648 \mathrm{~K}\left(375^{\circ} \mathrm{C}\right)$, and it is the same as that of the sample heat treated at $623 \mathrm{~K}\left(350^{\circ} \mathrm{C}\right)$ (Figures $6(\mathrm{~b})$ and (c)) and at $673 \mathrm{~K}\left(400{ }^{\circ} \mathrm{C}\right)$. The fraction of retained austenite is maximum in Figure 6(d).

Figures 7(a) and (b) show the optical micrographs of the steel S1 quenched and subsequently tempered at $673 \mathrm{~K}\left(400{ }^{\circ} \mathrm{C}\right)$ for 60 minutes and the steel S2 quenched and subsequently tempered at $623 \mathrm{~K}$ $\left(350{ }^{\circ} \mathrm{C}\right)$ for 90 minutes, respectively. The microstructures show tempered martensite. The temperature and time for tempering were selected in such a manner that the hardness of the quenched and tempered steel is comparable with that of the bainitic steel obtained by isothermal treatment. Figure 8(a) shows the result of the quantitative analysis for the volume fraction of bainite in the case of steels $\mathrm{S} 1$ and S2 heat treated at $623 \mathrm{~K}$ $\left(350{ }^{\circ} \mathrm{C}\right)$ for different holding durations. In steel $\mathrm{S} 1$ (Figures 2(a) through (d)), the constituent phases are bainite and martensite. The volume fraction of martensite is calculated by quantitative analysis, using an image analyzer. As the fraction of martensite is too little in steel S2 (Figures 5(a) through (d)), the micrographs were considered to consist of bainite and retained austenite. The amount of retained austenite was determined from the XRD data using the direct comparison method. ${ }^{[20]}$ The remaining fraction accounts for the bainite volume fraction in both steels. It can be seen that the volume fraction of bainite increases with the increase in holding time at the isothermal temperature (Figure 8(a)). The amount of retained austenite present in steel $\mathrm{S} 2$ is shown in Figure 8(b). The variation in the percentage of retained austenite lies within 5 to 8.5 pct.

Figures 9(a) through (c) show the AFM micrographs of $\mathrm{S} 1$ heat treated at $623 \mathrm{~K}\left(350{ }^{\circ} \mathrm{C}\right)$ for 30 minutes. A large fraction of bainite is clearly visible, with martensite being the minor phase constituting the microstructure. This clearly supports the optical observation, as shown in Figures 2 and 3. The sheaves of bainite can be seen in Figure 9(b). Figure 9(c) shows the topographical view of the region. The light regions are bainite, whereas the dark regions are martensite. Figures 10(a) through (c) show the AFM micrographs of the steel S2 heat treated at $623 \mathrm{~K}\left(350{ }^{\circ} \mathrm{C}\right)$ for 30 minutes. The microstructures confirm the presence of bainite and retained austenite. 

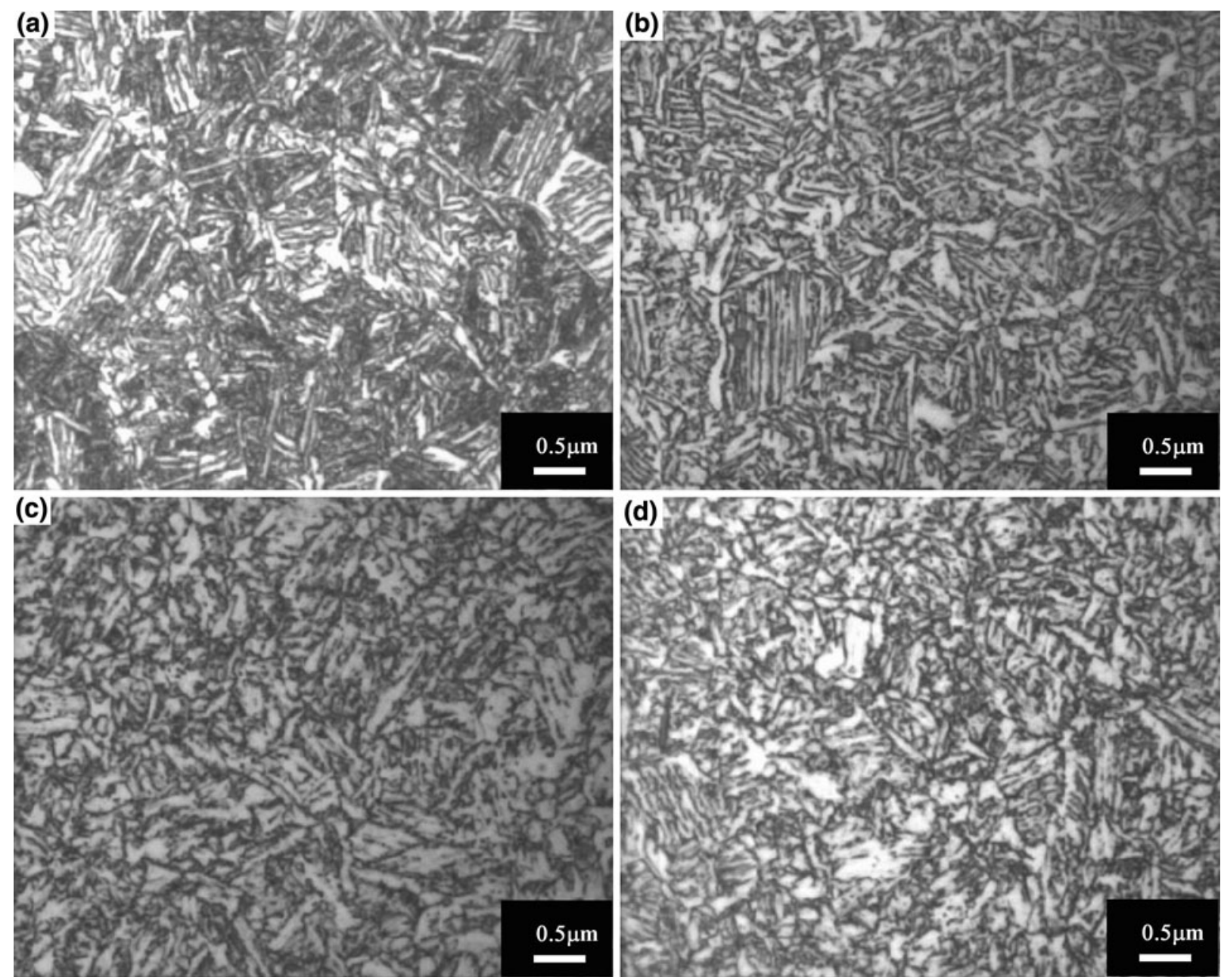

Fig. 5- Optical micrographs of steel S2 treated for a holding duration of $30 \mathrm{~min}$ at isothermal transformation temperatures of $(a) 598 \mathrm{~K}$ $\left(325{ }^{\circ} \mathrm{C}\right),(b) 623 \mathrm{~K}\left(350{ }^{\circ} \mathrm{C}\right),(c) 648 \mathrm{~K}\left(375^{\circ} \mathrm{C}\right)$, and $(d) 673 \mathrm{~K}\left(400{ }^{\circ} \mathrm{C}\right)$.

The individual sheaf can clearly be observed in Figures 10(b) and (c).

Figures 11(a) and (b) show the bulk hardness values of steels S1 and S2 heat treated at different isothermal holding temperatures for different durations. It can be noted that high hardness levels are achieved at lower transformation temperatures. Moreover, there is a gradual decrease in the hardness level as the holding time increases at the same isothermal temperature (Figure 11(a)). This can be attributed to the decreased amount of martensite that is present in the sample heat treated for a prolonged period at the same isothermal holding temperature. Higher hardness of the order of 40 to $48 \mathrm{HRC}$ was achieved in steel $\mathrm{S} 1$ due to the presence of the relatively larger amount of martensite in comparison to steel S2 (Figure 11(b)). It is interesting to note that the hardness level in the case of steel S2 gradually decreases with the increase in holding temperature. This can be attributed to the formation of upper course bainite (Figures 6(a) and (b)) and increased retained austenite when the isothermal holding temperatures are $648 \mathrm{~K}$ and $673 \mathrm{~K}\left(375^{\circ} \mathrm{C}\right.$ and $\left.400{ }^{\circ} \mathrm{C}\right)$ (Figures 6(c) and (d)). However, prolonged holding of the sample at the same holding temperature does not show any significant variation in the hardness (Figure 11(b)).

From the preceding discussion, the following general outcomes regarding microstructural evolution can be drawn.

(1) With the increase in the transformation temperature, the sheaf thickness increases for both steels S1 and S2. Holding duration does not produce any significant variation.

(2) The volume fraction of bainite increases with the increase in holding duration.

Figure 12 shows a representative stress strain curve for the steel S2 isothermally treated at $623 \mathrm{~K}\left(350{ }^{\circ} \mathrm{C}\right)$ for a holding duration of 30 minutes. Figure 13(a) shows the variation of yield stress (YS) and ultimate tensile stress (UTS) along with total percentage elongation and percentage reduction in area of steel $\mathrm{S} 1$ heat treated at $573 \mathrm{~K}$ and $623 \mathrm{~K}\left(300{ }^{\circ} \mathrm{C}\right.$ and $\left.350{ }^{\circ} \mathrm{C}\right)$ for 30 minutes. There is a drop in both the YS and UTS along with a corresponding increase in the total elongation and percentage reduction in area as the isothermal holding temperature increases to $623 \mathrm{~K}\left(350{ }^{\circ} \mathrm{C}\right)$. At $573 \mathrm{~K}\left(300{ }^{\circ} \mathrm{C}\right)$, the strength levels achieved are quite 

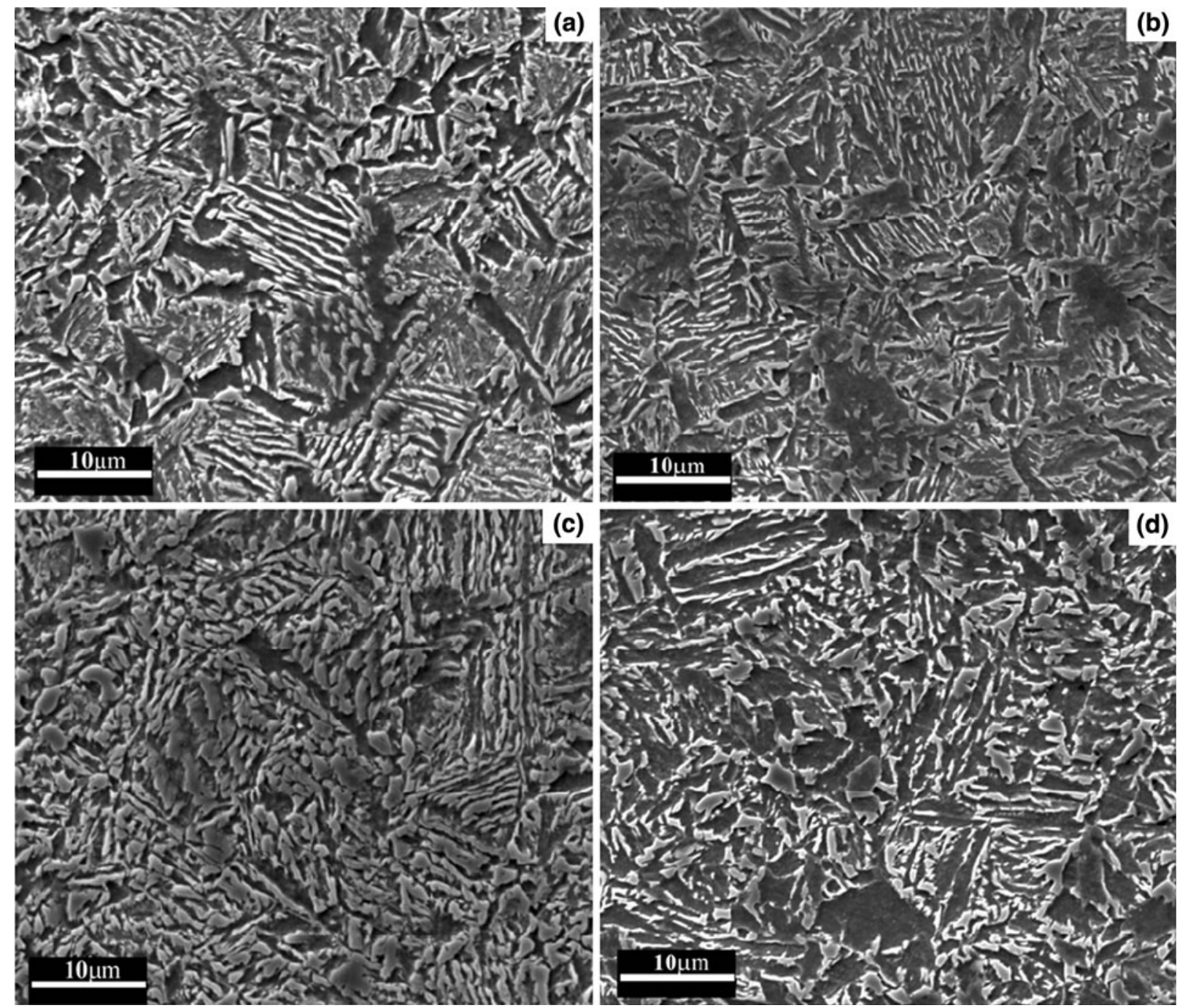

Fig. 6- SEM micrographs of steel S2 treated for $30 \mathrm{~min}$ at isothermal transformation temperatures of $(a) 598 \mathrm{~K}\left(325{ }^{\circ} \mathrm{C}\right),(b) 623 \mathrm{~K}\left(350{ }^{\circ} \mathrm{C}\right)$, (c) $648 \mathrm{~K}\left(375^{\circ} \mathrm{C}\right)$, and $(d) 673 \mathrm{~K}\left(400{ }^{\circ} \mathrm{C}\right)$.
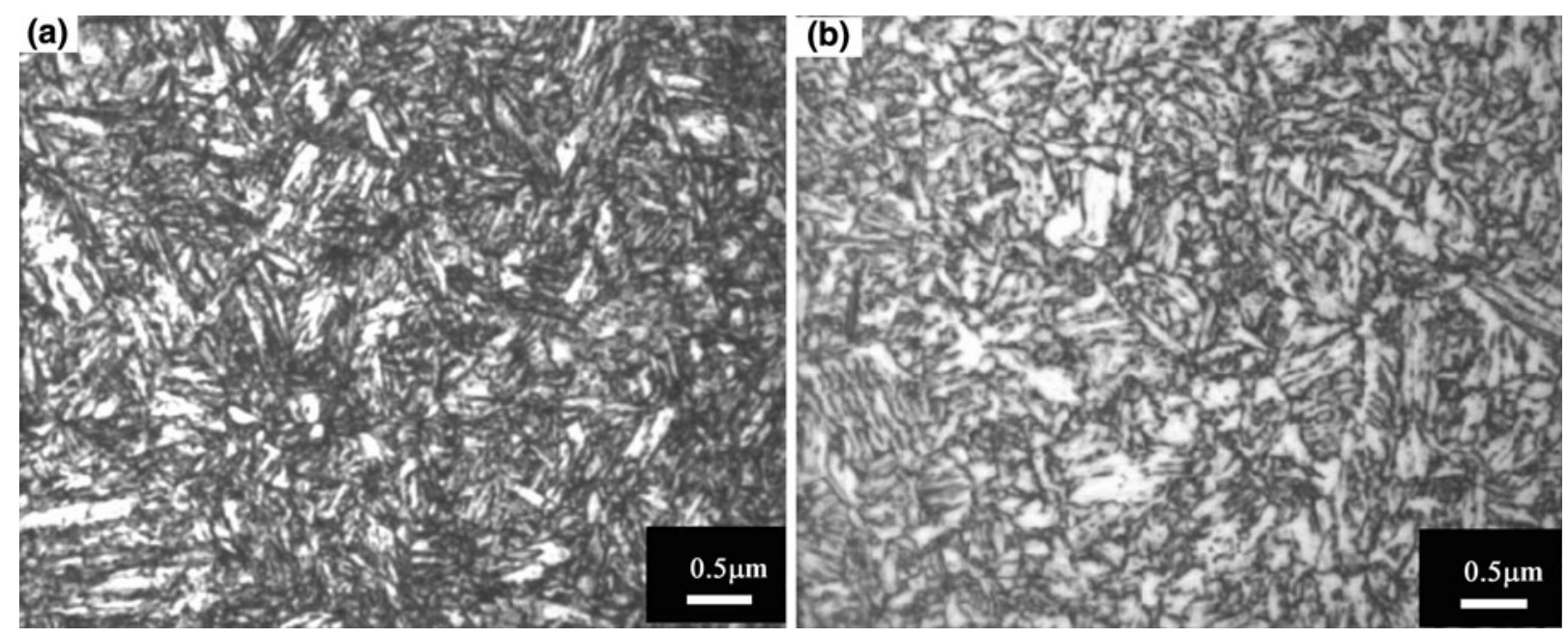

Fig. 7-Optical micrographs of $(a)$ steel S1 quenched and subsequently tempered at $673 \mathrm{~K}\left(400{ }^{\circ} \mathrm{C}\right)$ for 60 min and $(b)$ steel S2 quenched and subsequently tempered at $623 \mathrm{~K}\left(350^{\circ} \mathrm{C}\right)$ for $90 \mathrm{~min}$. 


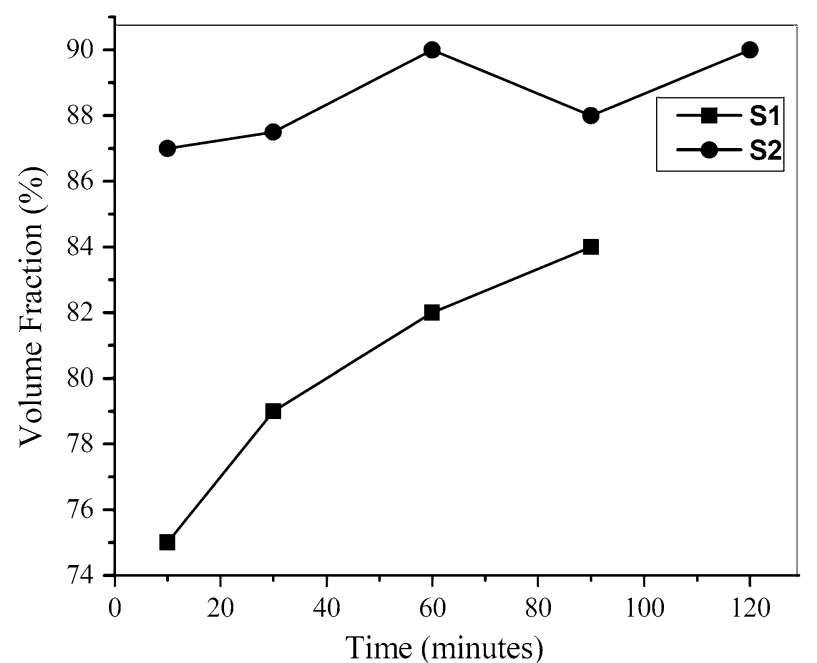

(a)

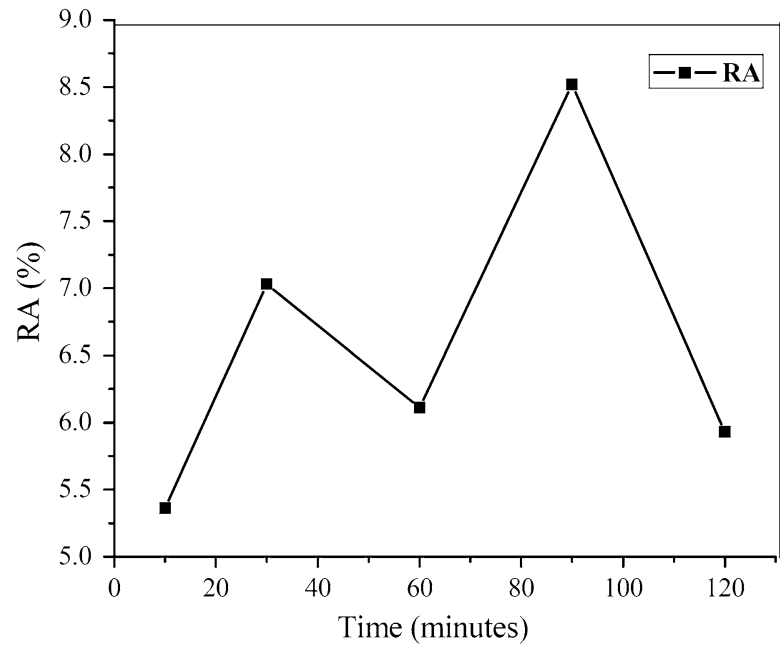

(b)

Fig. 8- (a) Volume fraction of bainite for steels $\mathrm{S} 1$ and $\mathrm{S} 2$ isothermally treated at temperature $623 \mathrm{~K}\left(350{ }^{\circ} \mathrm{C}\right)$ for different holding durations and $(b)$ amount of retained austenite present in $\mathrm{S} 2$.

high but the elongation becomes very poor. The sample heat treated at $623 \mathrm{~K}\left(350{ }^{\circ} \mathrm{C}\right)$ shows YS of $1336 \mathrm{MPa}$ with an appreciable elongation of 12 pct. Figure 13(b) shows the same variation for different holding durations at $623 \mathrm{~K}\left(350{ }^{\circ} \mathrm{C}\right)$ for steel $\mathrm{S} 1$. As the strength decreases, the percent elongation and percent reduction in area increase.

Figure 14(a) shows the variation of YS and UTS along with the total elongation and percent reduction in area of steel S2 heat treated at different transformation temperatures for 30 minutes. At $623 \mathrm{~K}\left(350{ }^{\circ} \mathrm{C}\right)$ and 30 minutes, the sample shows a peak in the YS and UTS data (of the order of $1550 \mathrm{MPa}$ ) and a high ductility (15.5 pct). The elongation and percent reduction in area increase as the strength decreases with an increase in temperature. Figure 14(b) shows the same variation for steel S2 heat treated at $623 \mathrm{~K}\left(350{ }^{\circ} \mathrm{C}\right)$ for different holding durations. Interestingly, with the increase in holding duration, the YS and UTS are found to decrease after reaching a peak value for 30 minutes, while the percent elongation and percent reduction in area increase. The mechanical properties of the quenched and subsequently tempered samples in the case of steel S1 were compared with that of the as-processed and heat-treated sample at the isothermal holding temperature of $623 \mathrm{~K}\left(350{ }^{\circ} \mathrm{C}\right)$ for 30 minutes (Table III). The same comparison was shown for steel S2. The tempering parameters are $673 \mathrm{~K}\left(400^{\circ} \mathrm{C}\right)$ with a holding time of 60 minutes for steel $\mathrm{S} 1$ and $623 \mathrm{~K}\left(350{ }^{\circ} \mathrm{C}\right)$ with a holding time of 90 minutes for steel S2. The steel sample heat treated isothermally shows a much better combination of high strength and large ductility than that of the quenched and subsequently tempered and as-processed samples (Table III).

The optical micrographs for S1 at $623 \mathrm{~K}\left(350^{\circ} \mathrm{C}\right)$ for different holding durations in Figures 2(a) through (d) show the variation in the amount of the phases present. As concluded earlier, with the progress of the isothermal transformation, the volume percent of bainite is found to increase, as shown in Figure 8(a). In steel S2, the bainite volume fraction is greater compared to that of steel $\mathrm{S} 1$, and this is expected due to its faster kinetics. As the weight percent of carbon increases in the retained austenite, it becomes enriched in carbon, which is more stable to martensite transformation. The hardness values for S1 in Figure 11(a) decrease with an increase in holding duration due to the decrease in the volume fraction of martensite, which is formed from the untransformed austenite during quenching (Figure 8(a)) and formation of upper bainite. The hardness trend in Figure 11(b) for steel S2 shows a variation according to the bainite volume fraction and the scale of the microstructure, as indicated by the relative size of bainite lathes with respect to the micron bar (Figures 5, 6 , and 10). With increasing length scale of microstructure because of increasing temperature, the hardness was observed to decrease. It is evident from Figure 13(a) that the YS decreases with the increase in the isothermal holding temperature. Also, it can be seen that there is a decreasing trend with increasing holding duration after the initial increase in YS and UTS. It can be seen that remarkable values of YS (1800 $\mathrm{MPa})$ in the case of the sample of $\mathrm{S} 1$ heat treated at $573 \mathrm{~K}\left(300{ }^{\circ} \mathrm{C}\right)$ for 30 minutes were achieved but with a compromise in the total elongation ( $\sim 6 \mathrm{pct})$. The high strength level can be attributed to the formation of a large amount of martensite due to slow transformation rates at the lower isothermal holding temperature. The improvement in ductility over the quenched and tempered sample (Table III) is due to the presence of the softer bainitic phase.

The presence of carbide precipitation in bainitic sheaves can be of major concern. ${ }^{[10]}$ In the present steels, no carbide was detected in XRD patterns (Figure 1). It is known that the precipitation of carbides from austenite can be suppressed by adding sufficient silicon to the steel. ${ }^{[17,21]}$ However, Chakraborty et al. ${ }^{[22]}$ observed carbides even in the XRD pattern after 


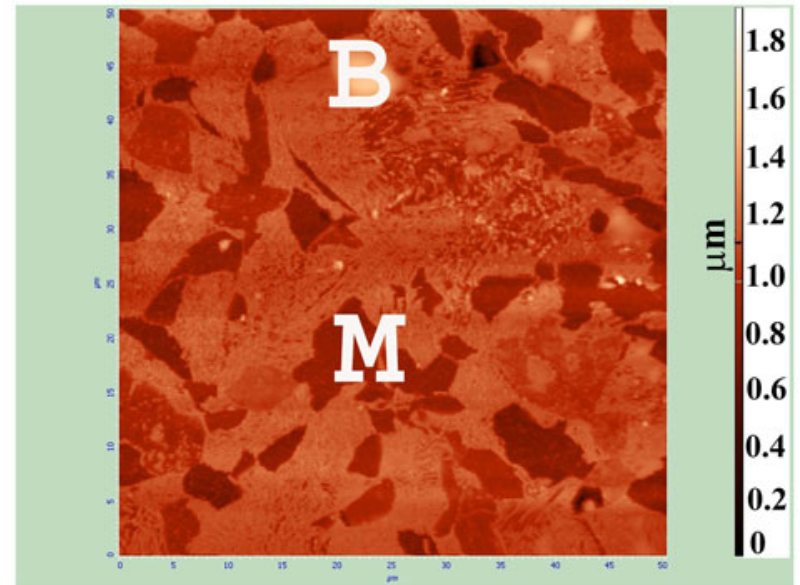

(a)

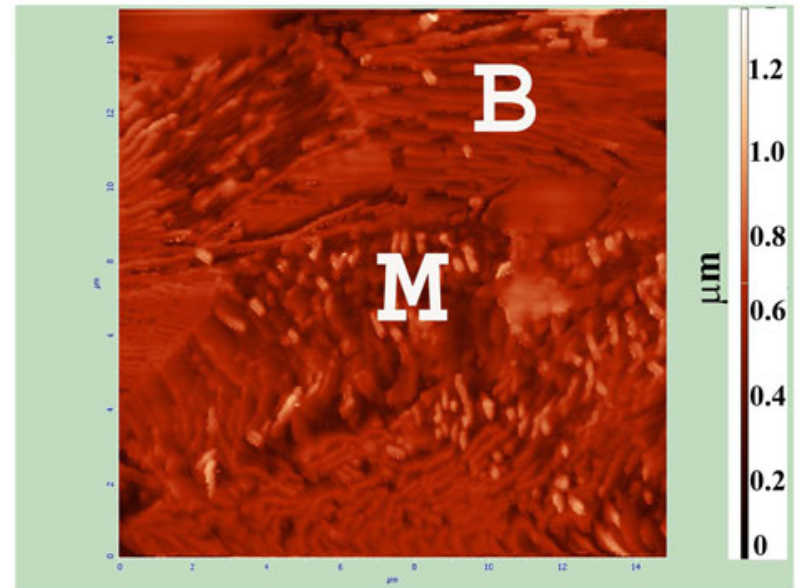

(b)

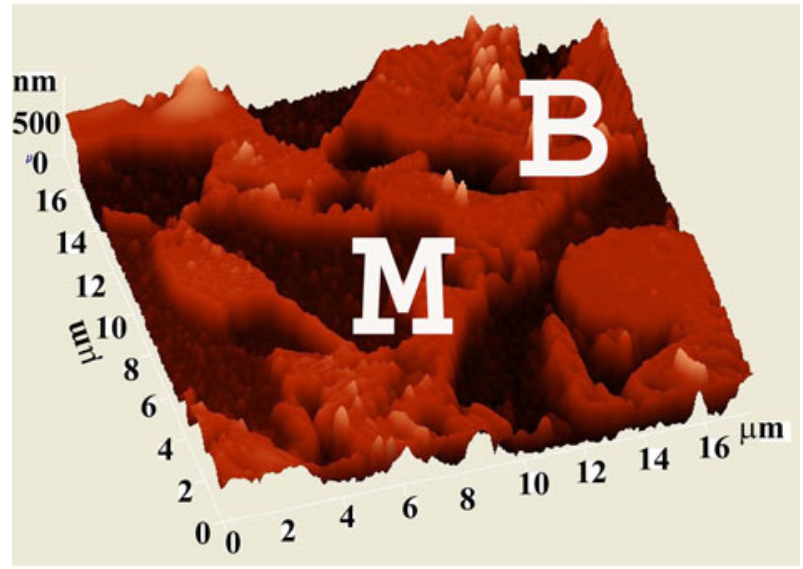

(c)

Fig. 9-Typical AFM images of the steel $\mathrm{S} 1$ treated for $30 \mathrm{~min}$ at isothermal transformation temperature of $623 \mathrm{~K}\left(350{ }^{\circ} \mathrm{C}\right)$ showing (a) 2-D surface topography of scanning area $50 \times 50 \mu \mathrm{m}^{2}$, (b) 2-D surface topography of scanning area $15 \times 15 \mu \mathrm{m}^{2}$, and (c) 3-D surface topography of scanning area $16 \times 16 \mu \mathrm{m}^{2}$.

austempering. The carbon content in the steel used by them is much higher (1.1 pct) and the silicon content $(0.27 \mathrm{pct})$ is much lower than that of steels $\mathrm{S} 1$ and $\mathrm{S} 2$ in the present case (Table I). Hence, it is probable that higher silicon content ( $1.76 \mathrm{pct})$ as well as much lower

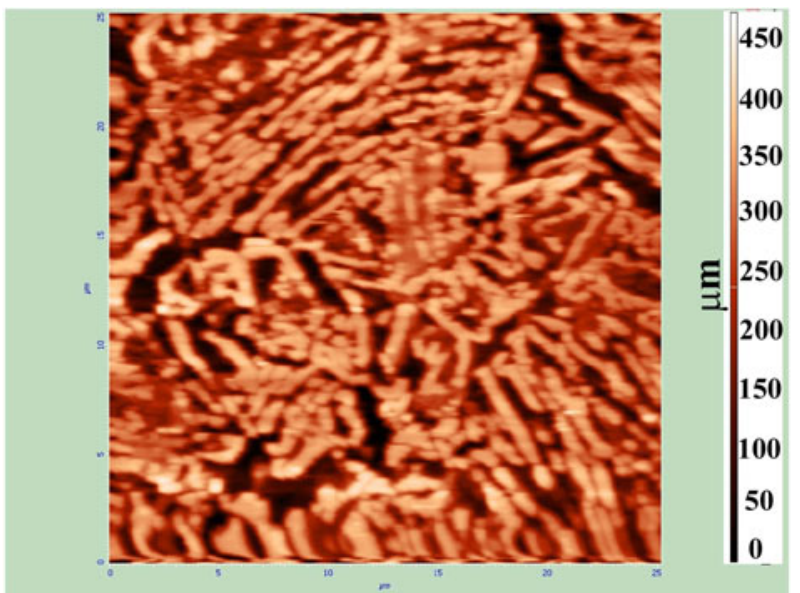

(a)

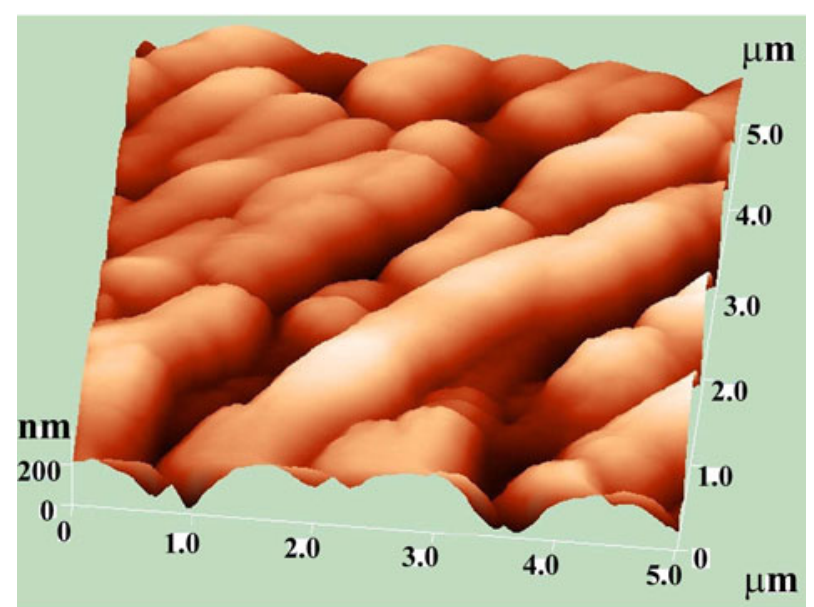

(b)

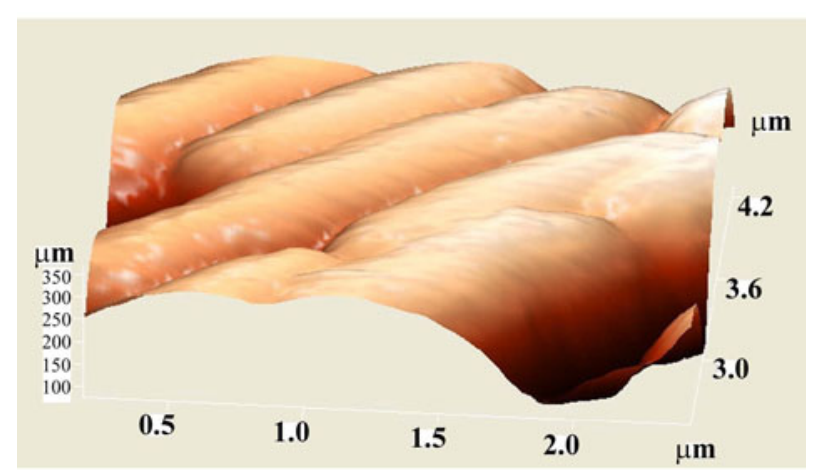

(c)

Fig. 10-Typical AFM images of the steel S2 isothermally treated for $30 \mathrm{~min}$ at isothermal transformation temperature of $623 \mathrm{~K}$ $\left(350{ }^{\circ} \mathrm{C}\right)$ showing (a) 2-D surface topography of scanning area $50 \times 50 \mu \mathrm{m}^{2},($ b) 2 -D surface topography of scanning area $5 \times 5$ $\mu \mathrm{m}^{2}$, and (c) 3-D surface topography of scanning area $2.0 \times 4.2$ $\mu \mathrm{m}^{2}$.

carbon content $(0.3 \mathrm{pct})$ in steel $\mathrm{S} 2$ does not lead to any carbide precipitation. Even in steel S1, carbon content $(0.47 \mathrm{pct})$ is less than half the carbon content and the silicon content $(1.22 \mathrm{pct})$ is almost 4 times the silicon content of the steel studied by Chakraborty et al. ${ }^{[22]}$ Thus, it is expected that the possibility of carbide precipitation in steel S1 is more than that of steel S2; 


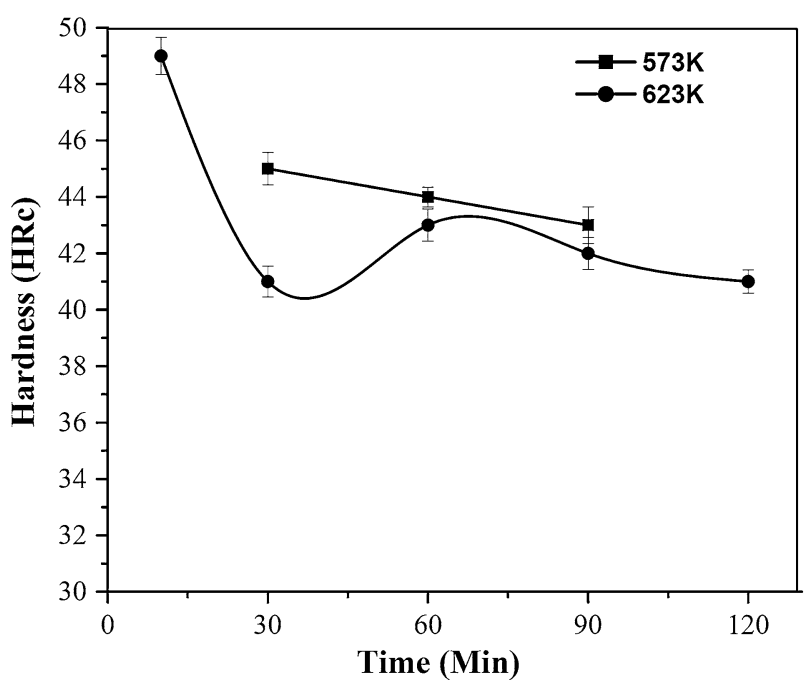

(a)

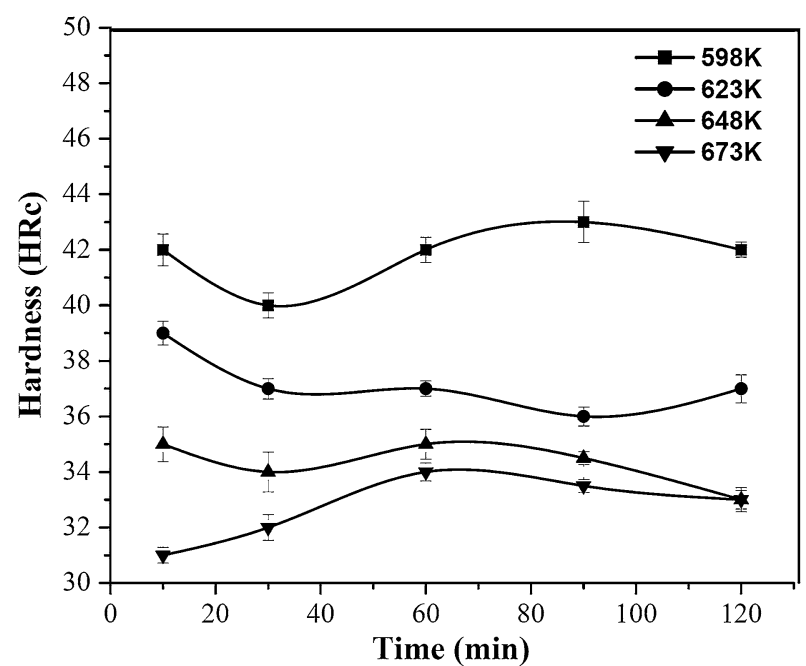

(b)

Fig. 11-Rockwell hardness values of $(a)$ steel S1 and $(b)$ steel S2 isothermally treated at different temperatures and holding durations.

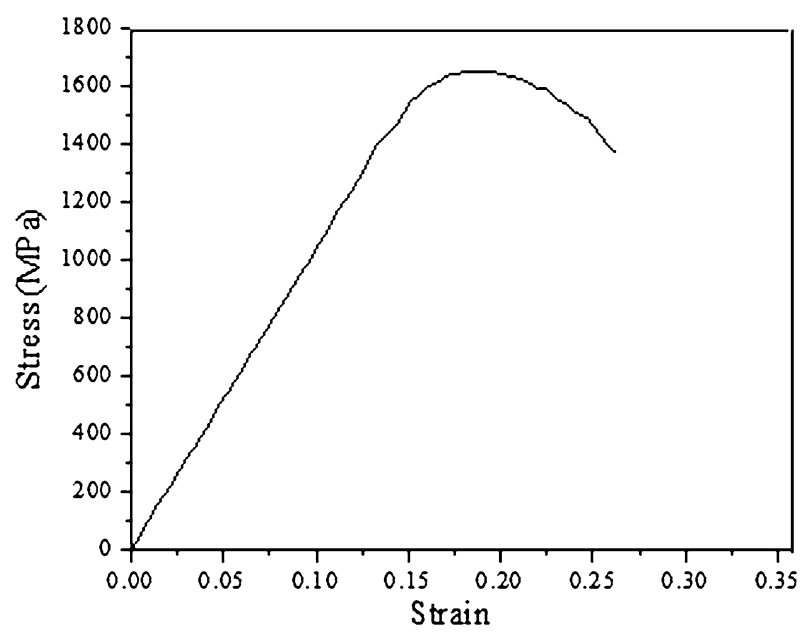

Fig. 12-Representative stress strain curve of steel S2 isothermally treated at $623 \mathrm{~K}\left(350{ }^{\circ} \mathrm{C}\right)$ for a holding duration of $30 \mathrm{~min}$.
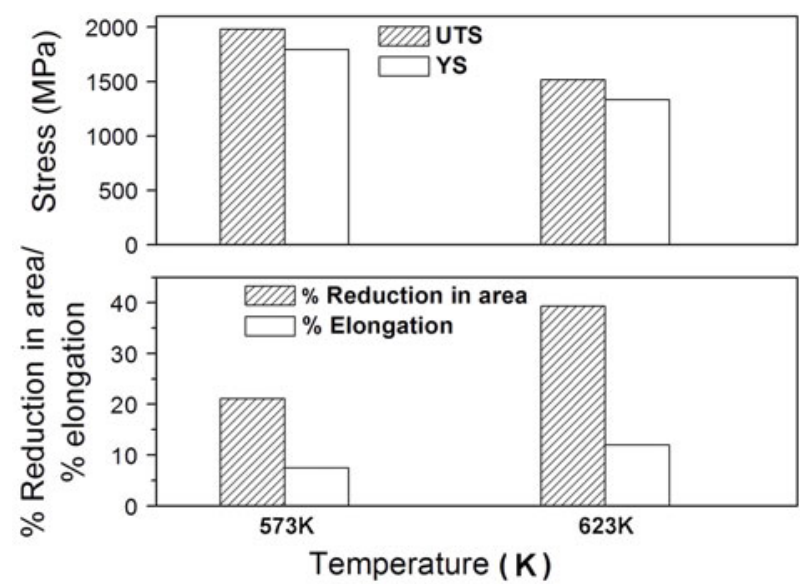

(a)

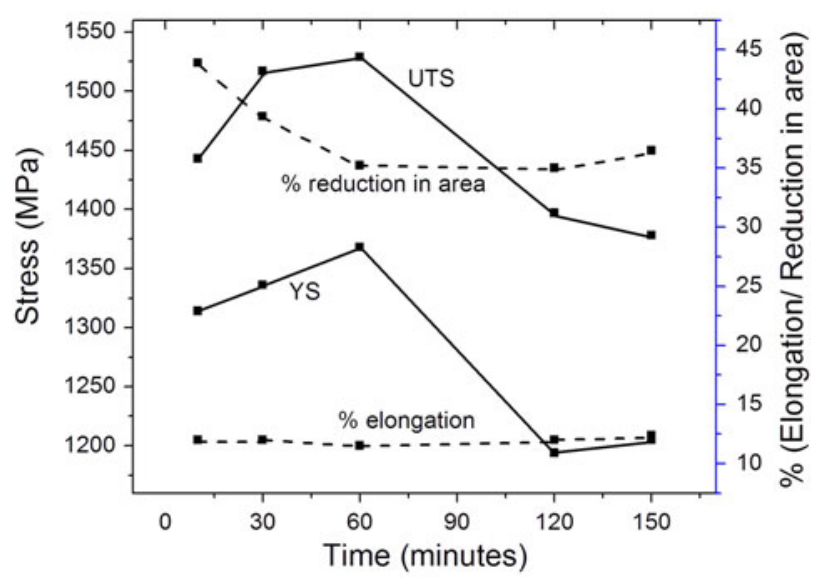

(b)

Fig. 13-Variation of yield stress (YS) and ultimate tensile stress (UTS) along with total elongation and reduction in area for steel S1 (a) isothermally treated at $573 \mathrm{~K}$ and $623 \mathrm{~K}\left(300{ }^{\circ} \mathrm{C}\right.$ to $\left.350{ }^{\circ} \mathrm{C}\right)$ for a holding duration of $30 \mathrm{~min}$ and $(b)$ isothermally treated at $623 \mathrm{~K}$ $\left(350{ }^{\circ} \mathrm{C}\right)$ for different holding durations.

still, the possibility of formation of carbide is much less compared to the steel used by Chakraborty et al. ${ }^{[22]}$ and hence, carbide is not detected by XRD. In addition, Caballero and Bhadeshia ${ }^{[5]}$ worked with a steel containing 0.98 wt pet $\mathrm{C}, 1.46 \mathrm{wt}$ pet $\mathrm{Si}, 1.89 \mathrm{wt}$ pet $\mathrm{Mn}$, 1.26 wt pet Mo, and 0.09 wt pet $\mathrm{V}$. It is very clear from their detailed TEM studies that lower bainite formed at $473 \mathrm{~K}\left(200^{\circ} \mathrm{C}\right)$ for 15 days failed to reveal carbides in the micrographs. More importantly, the carbon content in the steel studied by Caballero and Bhadeshia ${ }^{[5]}$ is 0.98 pct, which is almost double that of steel S1 and 3 times than that of steel S2. This suggests that silicon of the level of $1.46 \mathrm{pct}$ is sufficient to suppress precipitation of carbides in bainite. Hence, the possibility of carbide precipitation in the present steels with relatively much lower carbon content and much higher silicon content compared to the steels used by Chakraborty et al. ${ }^{[22]}$ and Caballero and Bhadeshia ${ }^{[5]}$ is very much negligible. Even a very high-magnification SEM micrograph (Figure 16) of steel S2 isothermally transformed at $623 \mathrm{~K}\left(350{ }^{\circ} \mathrm{C}\right)$ for 30 minutes fails to reveal the presence of any carbide precipitation in the bainitic sheaves. 


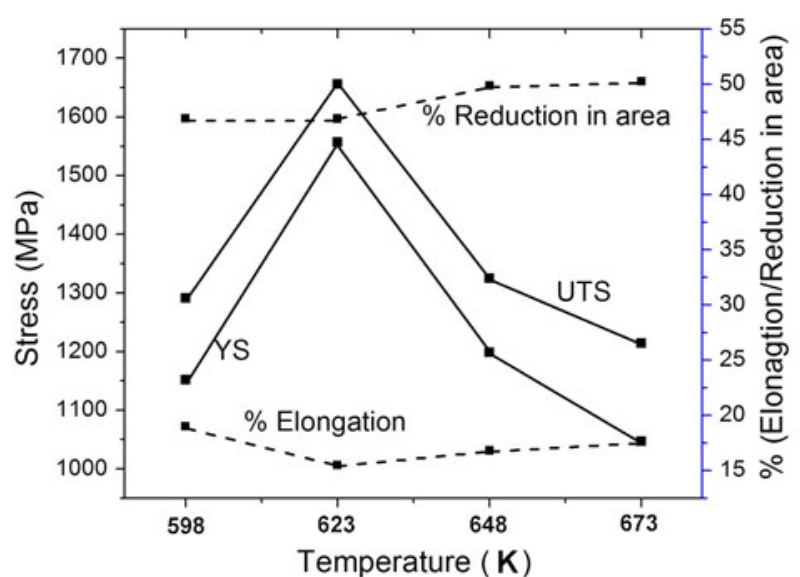

(a)

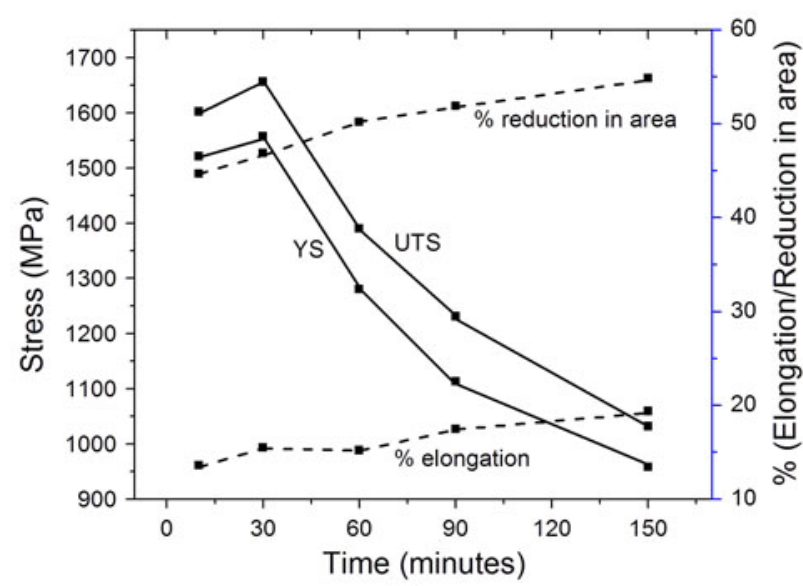

(b)

Fig. 14-Variation of YS and UTS along with total elongation and reduction in area for steel $\mathrm{S} 2(a)$ isothermally treated at $598 \mathrm{~K}$, $623 \mathrm{~K}, 648 \mathrm{~K}$, and $673 \mathrm{~K}\left(325{ }^{\circ} \mathrm{C}, 350{ }^{\circ} \mathrm{C}, 375^{\circ} \mathrm{C}\right.$, and $\left.400{ }^{\circ} \mathrm{C}\right)$ for a holding duration of $30 \mathrm{~min}$ and $(b)$ isothermally treated at $623 \mathrm{~K}$ $\left(350{ }^{\circ} \mathrm{C}\right)$ for different holding durations.

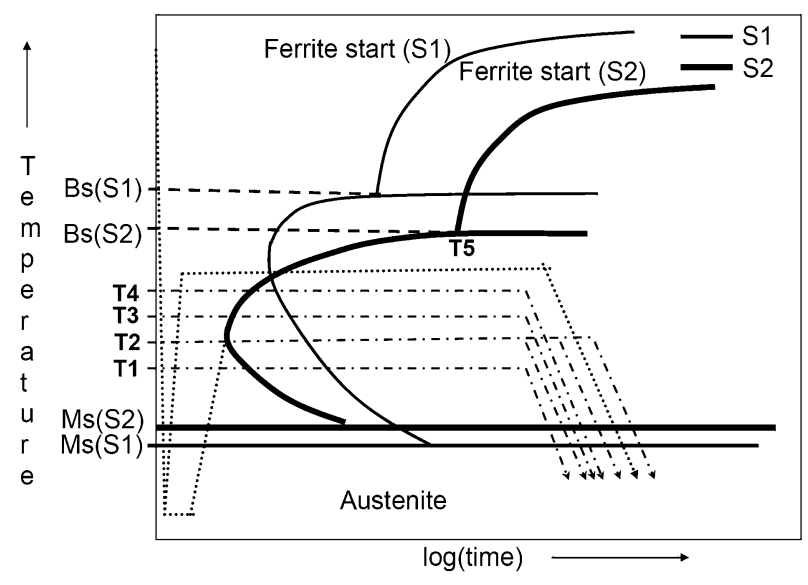

Fig. 15-Schematic representation of the TTT diagram showing the relative positions of the isothermal heat treatments for steels $\mathrm{S} 1$ and S2 and quenching and subsequent tempering treatment.

Large elongation in combination with relatively lower YS and UTS of the samples of the steel S2 heat treated at higher isothermal holding temperatures [648 $\mathrm{K}$ and
$673 \mathrm{~K}\left(375^{\circ} \mathrm{C}\right.$ and $\left.\left.400{ }^{\circ} \mathrm{C}\right)\right]$ is attributed to the presence of a large amount of retained austenite, as indicated in Figure 8(b). A YS of 1550 with a total elongation of 15.5 pct was achieved on the sample of steel S2 heat treated at the isothermal temperature of $623 \mathrm{~K}\left(350{ }^{\circ} \mathrm{C}\right)$ with a holding time of 30 minutes. This marks the optimization of strength and ductility. This result can be attributed to the presence of the optimum amount of retained austenite present in the microstruture in the form of film, which governs the ductility obtained in the steel. ${ }^{[23-25]}$ Retained austenite plays a role in blunting propagating cracks and reducing their effective fracture size; thus, it contributes to ductility and toughness. ${ }^{[12,15]}$ The strength is a function of the scale of the microstructure, as indicated earlier. In both steels, it is evident that at higher transformation temperatures, the strength values decreased. This can be attributed to two factors. Primarily, it would be a function of the sheaf thickness. At higher transformation temperature, the sheaf thickness can be seen to be greater for both steels in Figures 3 and 5; hence, the strength values decreased. Second, the increasing volume fraction of bainite at higher transformation temperatures results in a decrease in the strength.

The preceding observation can be schematically shown in Figure 15, where the relative positions of the isothermal heat treatments were marked on the timetemperature-transformation (TTT) diagram. $B_{s}$ and $M_{s}$ temperatures for both steels are indicated on the diagram. It is very clear that the bainite that forms in steel S1 at the higher isothermal holding temperatures is coarser and the fraction of martensite that is formed from the untransformed austenite is reduced (Figure 3 ) compared to the sample heat treated at $573 \mathrm{~K}\left(300^{\circ} \mathrm{C}\right)$. This leads to the lowering of the hardness and strength of the steel, as observed in Figure 11(a). It can even be seen that the microstructure of steel S1 due to isothermal heat treatment at a constant temperature contains a progressively lesser amount of martensite because of prolonged holding (Figure 2). This relates to the schematic too. Prolonged holding at the same isothermal temperature leads to lowering of the fraction of untransformed austenite, which transforms to martensite on quenching at the end of holding time. It is intersting to note that the fraction of retained austenite is maximum in the sample isothermally treated at $673 \mathrm{~K}$ $\left(400{ }^{\circ} \mathrm{C}\right.$ ) (Figures 5 and 6) for steel S2. However, the fraction of retained austenite in the samples isothermally treated at $648 \mathrm{~K}$ and $623 \mathrm{~K}\left(375^{\circ} \mathrm{C}\right.$ and $\left.350{ }^{\circ} \mathrm{C}\right)$ are almost on the same level, as seen from Figures 5(b) and (c) and Figures 6(b) and (c), whereas the fraction of retained austenite in the sample isothermally treated at $598 \mathrm{~K}\left(325^{\circ} \mathrm{C}\right)$ again increased. This observation in microstructure is clearly associated with the position of the holding temperatures, as indicated in Figure 15. The optimization in the microstructure on the basis of fraction of bainite, retained austenite, and length scale of microstructure is achieved when the isothermal treatment temperature is $623 \mathrm{~K}\left(350{ }^{\circ} \mathrm{C}\right)$ for a holding period of 30 minutes. This is also reflected with the appearance of peak in the YS and UTS in Figures 14(b) and (c) at the same temperature and time. It is 
Table III. Summary of the Best Mechanical Properties Attained with Their Processing Conditions

\begin{tabular}{|c|c|c|c|c|}
\hline & YS $(\mathrm{MPa})$ & UTS (MPa) & Elongation (Pct) & Hardness (HRC) \\
\hline \multicolumn{5}{|l|}{ Steel S1 } \\
\hline Air cooled & 586 & 955 & 10 & 19 \\
\hline Q\&T $\left(673 \mathrm{~K}\left(400{ }^{\circ} \mathrm{C}\right), 60 \mathrm{~min}\right)$ & 1166 & 1313 & 11.5 & 39 \\
\hline Isothermal transformation at $623 \mathrm{~K}\left(350^{\circ} \mathrm{C}\right)$ for $30 \mathrm{~min}$ & 1336 & 1517 & 12 & 41 \\
\hline \multicolumn{5}{|l|}{ Steel S2 } \\
\hline Air cooled & 549 & 887 & 24 & 23 \\
\hline Q\&T $\left(623 \mathrm{~K}\left(350{ }^{\circ} \mathrm{C}\right), 90 \mathrm{~min}\right)$ & 1441 & 1560 & 12 & 37 \\
\hline Isothermal transformation at $623 \mathrm{~K}\left(350^{\circ} \mathrm{C}\right)$ for $30 \mathrm{~min}$ & 1557 & 1656 & 15.5 & 37 \\
\hline
\end{tabular}

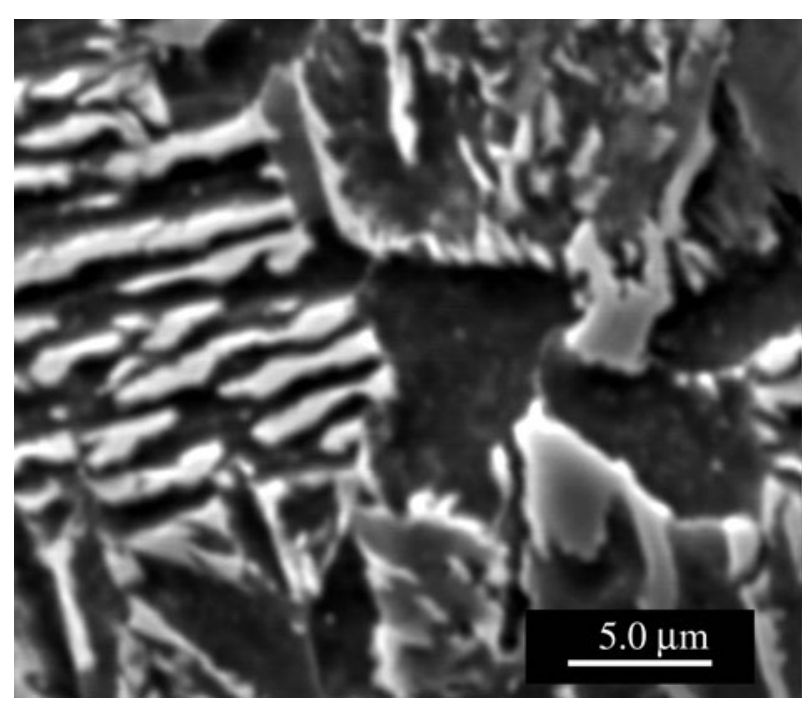

Fig. 16-High-magnification SEM micrograph of steel S2 isothermally treated at transformation temperatures of $623 \mathrm{~K}\left(350^{\circ} \mathrm{C}\right)$ for $30 \mathrm{~min}$.

interesting to note that the fraction of untransformed austenite at the end of the isothermal treatment transforms to martensite in the case of steel $\mathrm{S} 1$, whereas it remains as retained austenite in steel $\mathrm{S} 2$. This is also clearly evident in Figures 9 and 10, where the AFM images show the presence of martensite in steel S1 and retained austenite in steel S2 in addition to the major fraction of bainite. This could be related to the fraction of untransformed austenite as well as the composition of two different steels, but it is not understood fully. However, carbide was not observed during any of the treatments given to both steels. This must be related to the higher content of silicon in both cases. The same observation was also noted earlier, where Si acts as inhibitors for the precipitation of carbide. ${ }^{[18]}$ It is well understood that bainite rejects carbon to the remaining austenite during its formation. ${ }^{[5,26]}$ The carbon percentage in the untransformed austenite at the end of isothermal transformation in the case of S2 is suppressed higher than that in the samples of S1. This is also evident in Figure 15, where it was observed that the formation of bainite is greater in the case of steel $\mathrm{S} 2$ compared to steel $\mathrm{S} 1$ at all the isothermal temperatures (Figure 8(a)).

The quenching and subsequent tempering treatment showed a best result of $1166 \mathrm{MPa}$ as YS and $1313 \mathrm{MPa}$ as UTS with a total elongation of 11.5 pct for steel S1
(Table III). However, these values are significantly lower than those obtained by isothermal transformation to bainite. The best result obtained for this steel from the isothermal transformation route is YS of $1330 \mathrm{MPa}$, UTS of $1517 \mathrm{MPa}$, with a total elongation of 12 pct. For steel S2, the quenching and tempering treatment shows a best result of YS of $1440 \mathrm{MPa}$ and UTS of $1560 \mathrm{MPa}$ with an elongation of 12 pct (Table III), while the isothermal transformation route resulted in a YS of $1557 \mathrm{MPa}$ and UTS of $1656 \mathrm{MPa}$ with a total elongation of 15.5 pct. Exceptional mechanical properties obtained in the case of steel S2 are better than some of the steels developed by other investigators. ${ }^{[7,8,14]}$ The toughness for steel S2 was calculated empirically to be $236 \mathrm{MPa} \sqrt{\mathrm{m}} .{ }^{\text {[27] }}$ The combination of strength of $1557 \mathrm{MPa}$ and toughness $236 \mathrm{MPa} \sqrt{\mathrm{m}}$ is more impressive than a combination of the strength of $1600 \mathrm{MPa}$ and toughness of $130 \mathrm{MPa} \sqrt{\mathrm{m}}$ reported in the literature. ${ }^{[16,22]}$ The quenching and subsequent tempering heat treatment cycles for both steels are shown by the dotted line in Figure 15. Such a remarkable combination of mechanical properties is attributed to the bainite morphology.

\section{CONCLUSIONS}

Structure-property correlations were developed for the two steels ( $\mathrm{S} 1$ and $\mathrm{S} 2$ ) heat treated at different temperatures and time. The mechanical properties are a strong function of bainite, retained austenite, and martensite content in the steels. The volume fraction of bainite was found to increase with time at an isothermal holding temperature, and the volume fraction of the same is also closely associated with the position of isothermal temperature with respect to the TTT diagram. Finally, the mechanical properties of both the steels are also a strong function of the constituents (bainite, retailed austenite, and martensite) and length scale of the microstructures or finer bainite lathes. The addition of silicon resulted in carbide-free bainitic steels. Impressive results (the combination of strength of $1557 \mathrm{MPa}$ and toughness $236 \mathrm{MPa} \sqrt{\mathrm{m}}$ ) were obtained for intermediate temperature of transformation due to the optimization in the fraction of bainite and retained austenite. Finally, it can be concluded that the isothermal quenching temperature of $623 \mathrm{~K}$ $\left(350{ }^{\circ} \mathrm{C}\right)$ with a holding duration of 30 minutes was found to be the best processing condition for high silicon steel (S2). 


\section{REFERENCES}

1. C. Gracia-Mateo and F.G. Caballero: ISIJ Int., 2005, vol. 45, pp. $1736-40$.

2. H.K.D.H. Bhadeshia: Proc. 3rd Int. Conf. on Advanced Structural Steels, Gyeongju, Korea, Aug. 22-24, 2006, pp. 33-40.

3. R. Bakhtiari and A. Ekrami: Mater. Sci. Eng. A, 2009, vol. 525, pp. 159-65.

4. H.K.D.H. Bhadeshia and J.W. Christian: Metall. Trans. A, 1990 , vol. 21A, pp. 767-97.

5. F.G. Caballero and H.K.D.H. Bhadeshia: Curr. Opin. Solid State Mater. Sci., 2004, vol. 8, pp. 251-57.

6. L.C. Chang: Wear, 2005, vol. 258, pp. 730-43.

7. H.K.D.H. Bhadeshia and D.V. Edmonds: Met. Sci., 1983, vol. 17 pp. 411-19.

8. H.K.D.H. Bhadeshia and D.V. Edmonds: Met. Sci., 1983, vol. 17, pp. $420-25$.

9. Natalia Luzginova, Lie Zhao, and Jilt Sietsma: Mater. Sci. Eng. A 2007, vol. 448, pp. 104-10.

10. H.K.D.H. Bhadeshia: Mater. Sci. Forum, 2005, vols. 500-501, pp. 63-74.

11. H.K.D.H. Bhadeshia and D.V. Edmonds: Acta Metall., 1980, vol. 28 , pp. $1265-73$

12. H.K.D.H. Bhadeshia: Acta Metall., 1981, vol. 29, pp. 1117-30.

13. J. Chakraborty, D. Bhattacharjee, and I. Manna: Scripta Mater., 2009, vol. 61, pp. 604-07.
14. P.M. Brown and D.P. Baxter: Mater. Sci. Technol., 2004, vol. 1, pp. 433-38.

15. F.G. Caballero, H.K.D.H. Bhadeshia, K.J.A. Mawella, D.G. Jones, and P. Brown: Mater. Sci. Technol., 2001, vol. 17, pp. 512-16.

16. F.G. Caballero, H.K.D.H. Bhadeshia, K.J.A. Mawella, D.G. Jones, and P. Brown: Mater. Sci. Technol., 2001, vol. 17, pp. 517-22.

17. L.C. Chang and H.K.D.H. Bhadeshia: Mater. Sci. Eng. A, 1994, vol. 184, pp. L17-L19.

18. K. Andrews: J. Iron Steel Inst., 1970, vol. 24, pp. 3618-26.

19. Z. Zhao, C. Cheng, Y. Liu, and D.O. Northwood: J. Mater. Sci., 2001, vol. 36, pp. 5045-56.

20. B.D. Cullity: Elements of X-Ray Diffraction, Addison-Wesley, Boston, MA, 1959, pp. 388-96.

21. H.K.D.H. Bhadeshia and D.V. Edmonds: Metall. Trans. A, 1979, vol. 10A, pp. 895-907.

22. J. Chakraborty, D. Bhattacharjee, and I. Manna: Scripta Mater., 2008, vol. 59, pp. 247-50.

23. A. Barbacki: J. Mater. Process. Technol., 1995, vol. 53, pp. 57-63.

24. S. Zaefferer, J. Ohlert, and W. Bleck: Acta Mater., 2004, vol. 52 (9), pp. 2765-78.

25. A. Hanzaki and P. Hodgson: ISIJ Int., 1995, vol. 35, pp. 79-85.

26. W.C. Jeong, D.K Matlock, and G Krauss: Mater. Sci. Eng. A, 1993, vol. 165, pp. 9-18.

27. G.E. Dieter: Mechanical Metallurgy, 2nd ed., McGraw-Hill Book Co., New York, NY, 1976, pp. 282-83. 